\title{
Consumer Food Safety in Albania
}

\author{
Belinda Halilaj \\ Ph.D. Candidate, University of Vlora"Ismail Qemali", Albania \\ Email: belinda2012halilaj@gmail.com
}

\section{Doi:10.5901/ajis.2015.v4n3s1p168}

\begin{abstract}
At a time when new resources are needed for economic growth, the development of policies for customers is an area that can have a significant contribution to achieving the objectives for a safe consumer and a well-functioning market. Empowering consumers is not only a right, but has to do with creating an overall environment that enables them to use those rights and benefit from them, which means creating a system in which they can supported and which guarantees the safety of goods and services and effective protection of their economic interests when these are put at risk. Strategy for South Eastern Europe (SEE) 2020, which reflects the European 2020 highlights growth and smart, sustainable and inclusive. The policies for the protection of consumers enabling them to make well-informed choices that affect fair competition and support the goal of sustainable growth. SEE 2020 strategy aspires to empower consumers to play a pivotal role in the market, which requires strengthening their confidence in buying goods and services.
\end{abstract}

Keywords: Consumer, information security products, SEE strategy ect.

\section{Introduction}

Our country is going through a long period of transition, it is striking is that the market has a variety of food products. The findings made not all food products have security feature to have in a consumer market safe and protected from various dangers. For a customer as safe as possible it is essential to inform him. Consumer information and advice are essential elements of their defense. Increasing the ability of consumers to purchase knowledgeable brings undoubtedly increase the impact that they have on strengthening operational market, fostering innovation and economic growth, the demand for variety and quality of goods and services at competitive prices, market opening and growth employment. Guaranteeing the free movement of safe products on the market with the same technical requirements with European ones is the basis for any policy to customers and one of the fundamental freedoms laid down in the Treaty on the Functioning of the EU and one of the measures envisaged in the Strategy SEE 2020. An effective policy on the customer can change for the better life of EU citizens. Customer safe, informed and emancipated is the engine of the economy.

The internal market has played a central role in the economic challenges facing the membership which is Europe and forwarded to by EU citizens tangible benefits. ${ }^{1}$ The question arises what would you mean by consumer? 'Consumer' means any natural person who is acting for purposes which are in the framework of his trade, business, craft or profession that commits. ${ }^{2}$ In the Treaty of Maastricht it was agreed to create the European Union (EU), which would itself appointed the European Community (EC), membership established by the Treaty of Rome in 1950. The Treaty of Rome was signed in 1957 and entered into force in 1958. In Article 39 membership of this treaty are determined only five points on agricultural joint objectives. The fifth has the purpose to ensure that supplies reach consumers at reasonable prices. ${ }^{3}$ Article 40 provides that during the common organization of agricultural markets excluded "any discrimination between producers or consumers inside the Community". ${ }^{4}$ Any abuse carried out by a dominant firem inside the Common Market or in a substantial part of it shall be prohibited as incompatible with the Common Market to the extent that it may affect trade between Member States. ${ }^{5}$ In 1992 will be the Maastricht Treaty that will bring innovation in the field of consumer protection.

\footnotetext{
${ }^{1}$ http://ec.europa.eu/consumers/archive/overview/cons_policy/doc/cps_0713_it.pdf

2 Direttiva 2011/83/UE Del Parlamento Europeo e del Consiglio.

${ }^{3}$ Article 39/e The Treaty of Rome, http://www.epg.acp.int/fileadmin/user_upload/rometreaty2.pdf

${ }^{4}$ Ibid.

${ }^{5} \mathrm{lbid}$, Article 86
} 


\section{The Right to Consumer Information}

Policy on Consumer Protection includes a wide range of issues, such as consumer safety, informing the consumer, consumer education, protection of economic interests, compensation for consumer protection, market surveillance, consumer complaints, and their representation. This protection is for any good or service provided to the customer or used by them or is likely to achieve in the consumer market, consumers enjoy this protection without any discrimination or distinction. One of the points on which we will focus in this paper is to inform the consumer.

Consumer information and advice are essential elements of their defense. Only a well-informed consumer can maintain a critical attitude to the transparent variety of products and services in the market and can make an informed choice, contributing in this way to improve the quality of products and services. Some companies can do advertising preliminary prior to introduction of a product on the market in order to take measures for the protection of consumers through various forums or by voting online without possibility for identification of the individual to express suggestions, with the purpose of expressing very free of opinion on various products or goods, whether this good will enjoy a rich or poor, or no gender or racial differences.

Information and advice given to consumers must be independent, reliable, accurate and decentralized, in order to ensure the achievement of the right of ensuring social justice between individuals. ${ }^{6}$ Food labeling is a necessary element for consumer information and ensuring its health, food must have relevant tags. Providing information food will pursue a high level of protection of health and the interests of consumers by providing the basis for consumers to make informed choices and the use of food safety, in particular with regard to considerations of health economic, environmental, social and ethical. ${ }^{7}$

The customer enjoys protection from any commercial practice, misleading which contains false information. ${ }^{8}$ By law, merchants are obliged, within the limits of the relevant activities, to give consumers a complete and accurate set of goods and services or to be placed on the market. The data must be true, accurate and clear for all of the goods and services, as well as their trading conditions. The only persons who can provide information appropriate and necessary for the consumer on goods or services are traders who place in the market it. Law "On protection of consumers" explicitly sets of data attributes and their contents.

Data must be true, accurate, clear all of the goods or service, but also for their trading conditions. Traders forced on the premises of their business activities not discriminated against consumers, make the exposure of goods on customer's request, if the nature of the commodity permits this. Must meet sanitary conditions, to provide the declaration of conformity where their production is based, in cases where it is required.

\section{Food Safety}

During the last 5 years our country has undertaken a series of horizontal and sectoral initiatives field of consumer protection policy. These initiatives have been taken in implementation of this common strategy "Consumer Protection and Market Surveillance for 2007-2013 and the Strategy" For the development of quality infrastructure in Albania. As a result of the economic downturn, the products that the customer buys on the market do not always provide guarantees, to development and effective implementation of a strong legal framework has a special importance, because it increases the confidence of consumers in the market. Consumer market growth brings increased purchases, the latter strengthening the local economy.

Strategy for Consumer Protection and Market Supervision 2014-2020, is a political document which places at its center aim to empower consumers and their active role in the market, exercising their rights and power of the informed choice to buy goods and services. ${ }^{9}$ This strategy is in addition to the measures envisaged in the previous Strategy for Consumer Protection and Market Surveillance (2007-2013), specifying the areas that will require more attention in the coming years 2014 to 2020 .

To provide a consumer protection Albanian government has been a priority of creating the legal framework and

${ }^{6}$ Article 3 of the Constitution of the Republic of Albania.

${ }^{7}$ Article 3, Regolamento (EU) 1169/2011 N. Parlamento Europeo e del Consiglio del 25 ottobre 2011, Gazzetta ufficiale dell'Unione europea $L 304$, pg. 26.

${ }^{8}$ Article 6, Direttiva 2005/29 / CE Del Parlamento Europeo e del Consiglio dell'11 maggio, 2005.

${ }^{9}$ The crosscutting strategy "On consumer protection and market supervision" 2014 - 2020, p.8. 
institutions in the field of food safety. Food safety is a matter of concern not only in our country but throughout Europe. Since 1980 consumers felt increasingly threatened by listeria in cheese, salmonella in eggs and chocolate, use of hormones in meat production, genetically modified vegetables. ${ }^{10}$

Legal structures and policies of the European Union directly $f$ avors certain practices that devalue the quality of food. ${ }^{11}$ Fall of avian influenza has been a disturbing factor on food safety for consumers in our market, as that offered protection gave no guarantees high as in neighboring countries.

Consumption of products seized by the disease constitutes a danger to the health of the population, causing damage to health, but underestimated and harmful effects on the economy as a result of not drawing with these product categories in the market as a result of sitting that consumer confidence.

To ensure the protection of the health of consumers must ensure effective functioning of each link in the food chain from farm to table..$^{12}$ Measures taken for consumer protection does not constitute a difference whether the products are manufactured in Albania or are inportuara from other countries, the implementation of their effect on equal terms. For this reason, the Albanian government has had and will continue its attention to strengthening the control and monitoring of foods produced and marketed in the Albanian market intended for human consumption and food for animal use. ${ }^{13}$

\subsection{Areas covered by the Law on Food.}

In terms of legislation, the Law "On Food" adopted in 2008 is harmonized with the acquis communautaire in the field of food safety, is intended to reduce, eliminate or prevent risks to consumer health through analysis of three basic components: assessment risk, risk management and risk communication in the field of food and feed, plant protection and agricultural inputs, ect...

Secondary legislation adapted to the European one includes package hygiene, microbiological criteria, the criteria health for products of animal origin imported contaminants food, food additives, materials in contact with food, labeling of food products, health requirements for aquatic products, food for children ect..

Besides developments in the legal field, a major achievement in terms of ensuring food security in the country is the materialization of the National Food Authority (NFA), as the institution responsible for the control of food products of animal origin, not animal, plants and plant products as and agricultural inputs and control of raw materials used in the food industry as well as eventual product. NFA became operational on 1 September 2010. Our country has made progress with regard to the legal framework in the field of food safety, despite this remains partially harmonized with the European one.

In Article 3 of Law No.9863, dated 28.1.2008 "Food" clearly defines what will not understand its food by:

1. "Food" or "food product" means any substance or product, whether processed, partially processed or unprocessed, determined to be or, for any reason, it is consumable for people. The term "food" also includes drinks, chewing gum, food additives and any other substance, intentionally, it becomes part of the food during processing, preparation or treatment.

2. The word "food" includes water:

a) used as drinking water for public supply of the population;

b) use and / or join the food during manufacture, preparation or treatment thereof;

c) packaged as table water, mineral water and spring water.

Protect the interests of consumer law, the protection of his interests is a key elemnte to design effective policies in the present and in the future. This law protects the interests of consumers and provides the basis for their selection of information needed for the consumption of food.Law to ensure protection has a preventive effect in these cases (Article 9):

a) forged or fraudulent practices;

b) violation of the quality of food by improper use of components;

c) any other practice that falsely directs consumers.

\footnotetext{
${ }^{10}$ Caoimhín MacMaoláin, "EU Food Law", Oxford - Portland Oregon 2007, ISBN-13: 978-1-84113-498-7, pg.1.

11 Ibidem.

12 The crosscutting strategy "On consumer protection and market supervision" 2014 - 2020, p.9.

${ }^{13}$ Ibidem.
} 
Any food that is not safe for human health can not be launched. Any food that is produced according to standards and is not harmful to health is safe. Foods that can cause a damage on human health, whether in the future are uncertain and can not be offered to consumers in the market for consumption. Product labeling is another area that is covered by this law. Imported products in our country must be labeled. Labels must be written in Albanian, be distinct, legible and understandable. Food, which is marketed, provided the label, recording: 14

a) the product name;

b) a list of ingredients;

c) the amount of specific ingredients or categories of ingredients;

d) the net quantity in the case of unpacked food;

e) date of minimum durability or, in the case of foods that pose a risk of microbiological standpoint, marked "used to ...";

f) any special condition of storage and / or use;

g) name or business name and address of the manufacturer, packager and / or dealer;

h) gi) country of origin;

i) instructions for use when food can not be used without it;

j) degrees alcoholic beverage volume, containing more than 1.2 percent of the volume of alcohol;

k) content or composition of GMOs and GMOs contained.

Food before placed on the market and labeled may be exercised an official control. Official food control includes one or more of the following activities: ${ }^{15}$
a) inspection;
b) sampling and analysis;
c) control the label and official documentation;
d) examination of the documentation for traceability;
e) review of self-control system.

\section{Conclusions}

Consumer protection in our country is a novelty, years before there were no special measures to ensure its protection. Policy-making for customers is an area that can have a significant contribution to achieving the objectives for a safe consumer and a well-functioning market. In this paper I stopped in the treatment of two points of customer information and the treatment of certain moments on food safety. First customer information is one of the most important policies related to it. Only a well-informed consumer can maintain a critical attitude transparent variety of products and services in the market and can make an informed choice, contributing in this way to improve the quality of products and services. Secondly, in terms of legislation, the Law "On Food" adopted in 2008 is harmonized with the acquis communautaire in the field of food safety and aims to reduce, eliminate or prevent risks to consumer health. Product labeling is another area that is covered by this law, the label must be written in Albanian, be distinct, legible and understandable. Besides developments in the legal field, a major achievement in terms of ensuring food security in the country is the materialization of the National Food Authority (NFA), as the institution responsible for the control of food products of animal origin, not animal, plant or plant products as and agricultural inputs and control of raw materials used in food industry as well as eventual product.

\section{References}

MacMaoláin.C, (2007). EU Food Law. Oxford - Portland Oregon, ISBN-13: 978-1-84113-498-7.

The Treaty of Rome.

Direttiva 2011/83/UE Del Parlamento Europeo e Del Consiglio.

The Constitution of the Republic of Albania.

Regolamento (UE) N. 1169/2011 Del Parlamento Europeo e Del Consiglio del 25 ottobre 2011, Gazzetta ufficiale dell'Unione europea L 304.

Direttiva 2005/29/CE Del Parlamento Europeo e Del Consiglio dell'11 maggio 2005.

\footnotetext{
${ }^{14}$ Article 36 of Law 9863, dated 28.1.2008 "Food".

${ }^{15} \mathrm{lbid}$, Article 38.
} 
The crosscutting strategy "On consumer protection and market supervision" from 2014 to 2020.

Law No.9863, dated 28.1.2008 "On Food".

http://ec.europa.eu/consumers/archive/overview/cons_policy/doc/cps_0713_it.pdf

http://www.epg.acp.int/fileadmin/user_upload/rometreaty2.pdf 